\title{
POTRET TRANSFORMASI MASYARAKAT PEGUNUNGAN JAWA STUDI KASUS: SIPETUNG KABUPATEN PEKALONGAN JAWA TENGAH
}

\author{
Fajri Rahman ${ }^{1}$
}

\begin{abstract}
This article will try to explain how agricultural transformation that occurred in Dukuh Sipetung, Tlogopakis, District Petungkriyono, Pekalongan Central Java. Agricultural transformation is basically the process of change in various aspects of agriculture. In this paper, there are three aspects that cause the transformation: population growth, market dynamics, and development agendas faced by society Sipetung. In addition, also described how people in Sipetung respond and interpretation the transformations occurring proficiency level.
\end{abstract}

\section{Keywords: Transformation, Agricultural Society, Sipetung Community}

\section{A. Pendahuluan}

$\mathrm{M}$ emasuki dukuh Sipetung, kita akan dihadapkan dengan pemandangan pegunungan dengan tutupan hutan yang menghijau lebat. Sekolompok pe mukiman terpusat di pinggir hutan yang dikelilingi oleh ladang-ladang milik masyarakat. Keberadaan masyarakat Sipe tung yang terletak di daerah pegunungan, membuat proses transformasi yang terjadi pada masyarakat tersebut berbeda dengan masyarakat di daerah dataran rendah. Perbedaan ini disebabkan petani pe gunungan merespons desakan komersial dan demogafi secara amat berbeda dengan petani di dataran rendah.

Hefner dalam penelitiannya di daerah pegunungan Jawa menjelaskan bahwa meskipun sangat dipengaruhi oleh berbagai hal yang terjadi di sekitarnya, masyarakat dataran tinggi berbeda dengan gambaran masyarakat pertanian di dataran rendah. Tatanan sosial tidak dikelaskan ke dalam kelompok-kelompok sosial. Kepe milikan tanah didasarkan pada kepemilikan individu dan hak waris tanah, bukan kepemilikan komunal. Kebanyakan tanah pertanian digarap oleh pemiliknya sendiri. Pola patron-klien yang sangat umum di pertanian sawah Asia Tenggara secara jelas juga tidak dikenal pada masyarakat pegunungan. Dinamika interaksi di dataran tinggi ditentukan oleh para petani menengah yang bebas. Orang gunung bergantung pada tanahnya sendiri, bukan "jaminan subsistensi" dari patron yang membawa hinya, untuk memenuhi kebutuhan hidup mereka (Hefner 1999:4).

Perbedaan antara masyarakat dataran rendah dan dataran tinggi menye babkan telah tejadinya perbedaan perlakuan dari pihak-pihak luar, terutama penguasa atau pemerintah, yang membawa dampak perubahan kepada masyarakat. Menurut Tania $\mathrm{Li}$, daerah pegunungan (dan juga pedalaman) Indonesia, telah terbentuk sebagai wilayah yang tersisin melalui perjalanan sejarah keterlibatan politik, ekonomi, dan sosial dengan daerah dataran rendah, yang sudah lama dan masih terus berlangsung. Ketersisihan ini pada akhirnya menyebabkan masyarakat pegunungan dan masyarakat pedalaman, identik dengan masyarakat yang terisolir. Padahal menurut Colombijn (yang dikutip oleh $\mathrm{Li}$ dalam Anthony Reid 1988), pusat-pusat konsen trasi penduduk Indonesia pada masa prakolonial bukanlah di daerah pesisir, melainkan di daerah pedalaman, dan khususnya di lembah-lembah dan dataran tinggi pegunungan. Pemusatan ini didasarkan atas alasan ekonomi dan politik (Li, 2002:11), bahkan Pujo Semedi (2006: 129) menjelaskan kalau pelabelan sebuah daerah sebagai daerah terisolir adalah mitos belaka. Sebuah mitos yang dibuat oleh penguasa, masyarakat, dan para ahli atau

\footnotetext{
${ }^{1}$ Penulis adalah dosen tetap jurusan Antropologi FISIP Universitas Andalas, Padang
} 
akademisi.

Salah satu bentuk mitos ini dapat dilihat pada penetapan hutan sebagai kawasan hutan lindung. Dalam melihat hutan lindung, Li menjelaskan bahwa karena hutan di Jawa hanya memberikan "bagian yang sangat kecil dari pendapatan nasional yang berasal dari hutan" (Barber 1989: 124), maka tujuan utama dari kegiatan pemerintah "mengelola hutan" di Jawa adalah mengon trol penduduk yang tinggal di daerah pedalaman ini, dan bukan untuk mencari pemasukan uang atau keuntungan. Pen tingnya hutan bagi proses perluasan kontrol negara terhadap daerah pedalaman berlangsung tidak hanya sekedar me nyangkut masalah pohon-pohonnya. Di pulau Jawa menurut Li, 50\% dari jumlah penduduk tidak memiliki lahan, namun 23\% dari luas lahan seluruhnya diklasifikasikan sebagai hutan negara, yang tidak boleh digunakan untuk kegiatan pertanian dan penggunaan lainnya, dan di dalam kawasan hutan negara, yang tersisa hanyalah bekasbekas hutan alam, dan tumbuhan jati dan pinus yang sangat tidak produktif. Padahal di perbatasan "hutan" ini terdapat enam ribu desa, dihuni 30 juta jiwa, yang sebagian besar di antaranya mendapatkan peng hasilan dari hutan (2002: 26-28).

Di daerah Petungkriyono, mitosmitos ini tergambar dengan pelabelan daerah ini sebagai daerah terisolir ke dua di Jawa Tengah sesudah daerah Karimun Jawa oleh pemerintah (Semedi 2006: 128). Kemudian mitos-mitos ini berlanjut dengan penetapan daerah Petingkriyono sebagai daerah Eko Wisata atau wisata alam oleh pemerintah Kabupaten Pekalongan. Peme rintah juga menyediakan sebuah tempat bagi masyarakat yang ingin berwisata dengan melihat kawasan hutan yang asri dan lengkap dengan fasilitas kempingnya yang disebutnya dengan camping ground. Namun, walaupun berada dalam kondisi yang "terisolasi", Petungkriyono bukanlah daerah yang benar-benar terisolasi. Ber bagai intervensi dengan kepentingan masing-masing ternyata sampai menyentuh kehidupan masyarakat.

\section{B. Pertumbuhan Penduduk dan Keterbatasan Lahan Pertaniannya}

$\mathrm{B}$ eberapa penelitian tentang kehidupan sosial ekonomi pedesaan Jawa mencatat bahwa masalah penduduk merupakan faktor penting yang menye babkan terjadinya kemiskinan dan perubahan sosial ekonomi pada masa sekarang ini. Hayami (1987:84-86) menje laskan bahwa Jawa merupakan daerah utama di dunia yang paling padat penduduknya. Masalah kependudukan yang utama di Indonesia adalah, bahwa Jawa, telah penuh sesak dengan lebih dari $60 \%$ dari seluruh penduduknya. Mayoritas penduduk tetap berada di sektor pedesaan, dan penduduk yang tetap bertambah ini, dengan keras menekan sumber-sumber daya tanah yang terbatas. Pemakaian tanah pertanian sudah lama melampaui titik di mana berlanjutnya perluasan tanah yang diusahakan benar-benar membahayakan keseimbangan ekologis. Namun, pertum buhan penduduk bukan hanya berimplikasi kepada masalah distribusi tanah sebagai lahan pertanian, akan tetapi juga menyangkut kepada masalah tenaga kerja. Keterbatasan lahan pertanian di daerah atas ini menurut Hefner (1999: 95103) sudah dimulai saat ditutupnya hutan pada tahun 1910 dan dengan adanya pembagian tanah pertanian terakhir milik pemerintah. Akibatnya para petani di daerah atas tidak lagi memiliki lebih banyak tanah kecuali tanah desa mereka sendiri. Dari tahun 1910 sampai dengan tahun 1925, para petani membuka tanah yang sebagian besar adalah tanah olahan di daerah pinggiran. Lereng-lereng hutan di sekitar komunitas digunduli dan kemudian ditanami dengan tanaman pangan. Pada fase akhir dari perluasan ini yakni tahun 1927, ratarata keluarga petani di daerah lereng memiliki 1,59 hektar tanah. Dengan pertumbuhan penduduk dan kepemilikan tanah per kapita yang berkurang, tantangan yang dihadapi adalah bagaimana mendapatkan hasil yang lebih banyak dari lahan yang terbatas/berkurang. Pada akhirnya petani daerah atas mengerjakan dua macam langkah intensifikasi pertanian yaitu: sistem tumpang sari dan terasering.

Untuk daerah Petungkriyono, keterbatasan lahan pertanian ini ada kaitannya dengan kebijakan pemerintah 
kolonial pada waktu itu. Pembentukan distrik Petungkriyono oleh pemerintah kolonial menurut Semedi (2006: 133-134) agaknya dilatarbelakangi oleh kepentingan ekosis temik. dengan adanya organ pemerintah di Petungkriyono, pemerintah kolonial dapat mengatur dan mengawasi agar wilayah hutan Petungkriyono tidak mengalami kerusakan dan mengakibatkan banjir dan pendangkalan sungai di dataran rendah Pekalongan. Kebijakan awalnya adalah dengan menutup sejumlah perkampungan dan tanah pertanian di Petungkriyono. Sebagai upaya untuk menjaga agar petani tidak memperluas tanah pertanian mereka dengan membuka hutan, pemerintah melakukan pemetaan dan sertifikasi tanah.

Tekanan jumlah penduduk dan keterbatasan lahan pertanian menyebabkan pentingnya melihat masalah distribusi lahan pertanian. Tanah merupakan faktor yang paling penting dalam produksi dan bagian utama dalam kelangsungan hidup petani. Ada dua macam kepemilikan tanah yang terdapat di Sipetung, pertama adalah tanah hak milik dan kedua adalah tanah dengan hak guna (kelola). Tanah hak milik di sini adalah tanah di mana sebuah rumah tangga atau individu memiliki hak hukum atas tanah tersebut sesuai dengan Undang-Undang Pertanahan Indonesia dan disyaratkan oleh peninggalan hak-hak yang telah diprak tekkan dalam komunitas itu. Sedangkan tanah hak kelola dilihat sebagai total area tanah yang dapat memberikan penghasilan kepada sebuah rumah tangga, apakah dengan penyewaan, pembagian hasil, Peminjaman, atau pemilikan (Hefner 1999: 193). Pemanfaatan lahan hutan oleh masyarakat Sipetung dikategorikan sebagai salah satu bentuk dari hak kelola ini.

Ada beberapa cara untuk mendapatkan kepemilikan lahan pertanian pada masyarakat Sipetung. Pertama adalah melalui pewarisan, kedua melalui pembelian, ketiga, melalui sewa atau bagi hasil, dan yang terakhir adalah dengan memanfaatkan lahan hutan milik pemerintah. Pembagian harta warisan di Sipetung, pada umumnya dilakukan secara adat, atau ketentuan yang sudah berlaku secara turun-temurun. Warisan dibagi kepada seluruh anak sesuai dengan keputusan dari orang tua. Cara yang kedua untuk memiliki lahan pertanian adalah dengan pembelian tanah. Dengan bertambahnya jumlah penduduk, lahan pertanian secara otomatis akan semakin sedikit. Dengan tidak adanya kemungkinan untuk membuka lahan pertanian baru, pembelian tanah merupakan salah satu cara bagi masyarakat Sipetung untuk mem perluas lahan pertaniannya. Selain melalui warisan dan pembelian, cara untuk mendapatkan tanah adalah dengan sistem sewa tanah dan sistem bagi hasil. Sewa tanah adalah si pemilik tanah menyewakan tanahnya kepada orang lain sesuai dengan harga yang disepakati, hasil dari lahan tersebut adalah milik si penyewa. Sistem sewa ini, walaupun jarang, sudah lazim terjadi di Sipetung. Lahan yang disewakan biasanya adalah lahan perkebunan.

Tekanan jumlah penduduk juga berdampak kepada masalah ketenaga kerjaan. Penyerapan tenaga kerja paling banyak terjadi di lahan persawahan. Masa tanam dan masa panen adalah saat-saat diperlukannya banyak tenaga kerja. Dulunya, aktivitas ini dilakukan dengan cara sambatan (gotong-royong). Petani yang panen beserta saudara-saudaranya ditam bah dengan warga yang sawahnya berdekatan saling tolong menolong untuk melakukan panen. Si petani biasanya hanya menyediakan makanan dan rokok buat warga yang ikut sambatan. Sebagai gantinya, dia juga akan ikut menolong sawah warga yang ikut menolongnya pada saat panen. Sekarang, sambatan mulai berubah. Sistem gotong-royong mulai berganti menjadi sistem upah. Warga yang ikut membantu memanen, tidak lagi cukup dibayar dengan makanan dan rokok, namun juga dengan uang. Tenaga kerja kooperatif sudah mulai berubah menjadi tenaga kerja upahan. Sambatan berlaku pada ruang lingkup yang lebih kecil, yaitu famili.

$$
\text { Perubahan sambatan atau }
$$

munculnya tenaga upahan di sektor pertanian ini disebabkan karena munculnya sumber ekonomi baru di luar Sipetung. Berkurangnya lahan pertanian, dan sedikitnya alokasi waktu di lahan sendiri, menyebabkan banyaknya waktu luang yang dimiliki oleh warga. Munculnya sumber ekonomi baru diluar Sipetung ditambah dengan semakin tingginya kebutuhan hidup, banyak warga Sipetung yang pada akhirnya pergi keluar untuk bekerja. Anak-anak muda mayoritas pergi ke kota untuk menjadi buruh konveksi, sementara orang dewasa dan 
orang tua menjadi buruh tani dan tukang bangunan di desa-desa lain. Banyak warga yang menjadi buruh tani di desa-desa lain dan kemudian menjadi buruh tani di desa mereka sendiri. Munculnya buruh tani juga disebabkan karena adanya kebutuhan akan buruh tani di sektor pertanian. Daerah Gumelem dan Simego dengan pertanian kentang, cabai dan bawangnya, meme rlukan banyak buruh tani. Beberapa warga di desa tetangga yang mempunyai kebun sengon yang besar juga memerlukan buruh tani pada masa awal penanaman.

Meningkatnya populasi juga berdampak kepada semakin tingginya mobilitas penduduk. Mobilitas ini keliha tannya cukup tinggi di kalangan pemuda. Dalam catatan pak bau, saat ini ada sekitar 19 orang pemuda yang sedang merantau ke Jakarta dan kota Pekalongan. Umumnya bekerja menjadi buruh konveksi dan pembantu rumah tangga. Saat ini hanya ada sekitar 5 orang pemuda yang masih tinggal di Sipetung. Mereka yang gagal dan tidak tahan di daerah rantau akan pulang ke Sipetung. Ada anggapan bahwa banyaknya pemuda Sipetung yang pergi merantau ini disebabkan karena ingin keluar dari tradisi bertani. Bahkan bagi para pemuda bekerja di luar sektor pertanian juga merupakan pembebasan dari kungkungan tradisi "menjadi buruh istri" atau "menjadi buruh mertua". Kehadiran mereka di dalam rumah tangga di dalam rumah tangga bukan lagi semata-mata sebagai tenaga kerja yang kelangsungan hidup dan harga dirinya sepenuhnya tergantung pada si pemilik lahan (Semedi, 2009: xxvii).

\section{Dinamika Pasar}

$\mathrm{P}$ erdagangan ini tidak hanya berdampak sebatas pada ekspansi perdagangan saja. Salah satu dampaknya adalah munculnya model-model pembelian baru dalam masyarakat (Hefner, 1999: 110). Sebelumnya pembelian hasil panen dilakukan setelah masa panen dila kukan, namun seiring dengan perkem bangan dan transformasi yang terjadi kemudian muncul model pembelian sebelum masa panen, seperti sistem ijon dan tebasan. Sistem ijon, yaitu model pembelian tanaman jauh sebelum tanaman tersebut siap dipanen, sementara tebasan yaitu pembelian yang dilakukan beberapa hari sebelum masa panen. Sistem ijon dan tebasan ini berlaku pada hasil perkebunan yang siap untuk dijual. Hasil pertanian yang sifatnya di tabung, seperti jagung, padi, dan kopi, tidak mereka jual dalam bentuk sistem ini. Kebanyakan sistem ini berlaku pada tanaman sengon, suren, nangka, mahoni.

Ekspansi perdagangan juga diiringi dengan pertumbuhan relasi-relasi part nership perdagangan yang teratur antara petani dengan pedagang. Relasi yang menimbulkan rasa saling percaya dan bentuk kerja sama yang saling mengun tungkan antara warga dengan pedagang. Contohnya hubungan antara warga dengan pedagang-pedagang langganan mereka di pasar Doro. Karena sudah berlangganan, warga selalu menjual hasil pertanian mereka ke pedagang tersebut. Pedagang pun selalu memberikan potongan harga kepada langganannya ketika dia berbelanja. Bahkan hubungan yang terjadi pun sampai kepada masalah pinjaman. Warga bisa mengambil barang dulu, ataupun meminjam uang kepada pedagang langganan. Pinjaman ini akan dibayarkan kembali pada waktu panen sudah dilakukan. Pola seperti ini juga berlaku kepada pedagang-pedagang yang datang ke daerah Sipetung.

Pasar yang sering dikunjungi oleh warga Sipetung adalah pasar di daerah Doro. Berbelanja di pasar Doro bukan hanya sekedar membeli kebutuhan pangan saja. Disana mereka juga membeli baju, sepatu, perhiasan sampai perabotan rumah tangga. Warga Sipetung berbelanja kebutuhan dapur biasanya untuk kebutuhan satu Minggu atau satu bulan. Ibu Sri misalnya, waktu berbelanja ke Doro, ia menghabiskan uang belanja sampai 800.000 rupiah, semuanya untuk keperluan dapur selama satu bulan. Selain tempat berbelanja, pasar Doro adalah tempat menjual hasil pertanian warga Sipetung.

Pedagang-pedagang banyak juga yang datang ke dukuh Sipetung. Mereka membawa barang dagangan mereka dengan berjalan kaki, memakai motor, sampai memakai mobil. Aneka barang datang, mulai dari aneka jajanan, seperti bakso, sate, sosis, es, dan tempur, ada juga yang menjual pakaian, ada juga yang menjual perabotan rumah tangga. Para pedagang ini tidak sekedar menjual dagangan saja. Ada juga pedagang yang 
datang untuk kemudian membeli hasil-hasil pertanian warga Sipetung.

Hubungan antara warga Sipetung dengan pedagang, baik yang di pasar Doro maupun yang datang ke Sipetung, bukan hanya sebatas hubungan jual beli saja. Sebagaimana yang dijelaskan di atas, antara warga dengan pedagang, sudah percaya satu sama lain. Warga bisa meminjam uang kepada pedagang langganan mereka di pasar. Uang pinjaman ini nantinya akan dibayar pada saat mereka menjual hasil pertanian mereka.

Warung pak Wandi juga memper lakukan sistem yang sama. Banyak warga yang berhutang ketika berbelanja di warung pak Wandi. Utang tersebut ada yang dibayar lagi dengan uang, ada juga yang dibayar dengan hasil pertanian. Warga juga banyak yang meminjam uang kepada pak Wandi dengan menggadaikan hasil pertaniannya. Hasil pertanian yang digadai ini seperti kopi, kolang-kaling, jahe, dan jagung.

\section{Kebijakan Pemerintah dan Agenda- agenda Pembangunan}

$\mathrm{P}$ eran pemerintah dalam masalah transformasi pertanian cukup signifikan. Hal ini dimulai sejak pemerintahan kolonial sampai pada pemerintah Indonesia. kedatangan Belanda ke wilayah nusantara bukan sekedar masalah pendudukan dan perdagangan saja, tapi juga memperkenalkan sejumlah tanaman komersial. Dua jenis tanaman yang paling berhasil selama pemerintahan Belanda adalah kopi dan tebu untuk gula (Hefner 1999: 64). Karena berada di daerah ketinggian, tebu tidak bisa tumbuh dengan baik sebagaimana halnya dengan kopi di Petungkriyono. Kemungkinan kopi masuk ke Petungkriyono pada abad ke 18, atas perintah Bupati Pekalongan dalam rangka memenuhi permintaan pasar yang dibuka oleh VOC. Tanaman kopi ini tidak ditanam khusus, tetapi sebagai tanaman setengah liar di hutan. Kopi dijual ke gudang kopi milik pemerintah yang terdapat di Sipetung untuk kemudian diangkut ke Pekalongan (Semedi, 2006: 131).

Kebijakan pemerintah di bidang pertanian juga muncul pada awal pemerintahan Indonesia. Pemerintah Orde Lama sudah mulai merintis usaha intensifikasi pertanian. Di awali dengan meluncurkan program padi sentra pada tahun 1959 sampai tahun 1962, disusul kemudian dengan program Demas (demonstrasi massal) (Asnawi, 1991: 198). Perlakuan pemerintah di sektor pertanian semakin intensif pada masa Revolusi Hijau. Varietas padi unggul, penggunaan pupuk kimiawi dan pestisida, serta pengendalian air, menjadi praktek pertanian yang diperkenalkan oleh pemerintah. Untuk menunjang keberhasilan produk unggulan tersebut, pemerintah mengeluarkan program Bimbingan Massal (BIMAS). Dalam program ini pemerintah memberikan kredit kepada petani untuk mendapatkan bibit, pupuk, dan pestisida, dan juga memberikan panduan tentang penggunaan dan pengelolaannya.

Pada masa Revolusi Hijau ini produksi beras selama waktu itu mengalami peningkatan. Surjo dan Soedarsono (1985: 34) menjelaskan bahwa selama periode 1965 sampai 1971 terjadi kenaikan produksi rata-rata $6,5 \%$ per tahun, dibanding pada tahun sebelumnya yang hanya $6 \%$ per tahun. Akan tetapi produksi hasil bumi selain beras mengalami penurunan. Pemerintah mulai menunjukkan perhatian yang lebih besar dalam tanaman lain ketika segala sesuatu menjadi jelas, yakni bahwa kebutuhan swasembada tidak hanya dapat dijamin dengan adanya beras saja. Tahun 1972-1973, kedelai, kacang, dan ketela pohon termasuk dalam program penyuluhan BIMAS, sehingga sedikitnya beberapa petani tegalan bisa memperoleh kredit untuk membeli pupuk. Setelah bertahun-tahun diabaikan, para petani tanah tegalan di Jawa mulai merasakan manfaat programprogram yang baru dan teknologi yang baru pula (Hefner, 1999: 135-137).

Pengenalan tanaman-tanaman dan teknologi baru oleh pemerintah kepada masyarakat menyebabkan terjadinya peru bahan kepada sistem pertanian masyarakat. Diperkenalkannya padi-padi varietas unggul kepada masyarakat, diiringi dengan perubahan dari pemakaian ani-ani kepada sabit. Dulunya masyarakat lebih intensif kepada pengolahan tanaman-tanaman po kok, namun sekarang mereka lebih intensif dalam pengelolaan tanaman-tanaman komersial, seperti selong, cengkeh, dan kopi. Tanaman pertanian yang baru ini juga diiringi dengan pemakaian pupuk kimiawi dan pestisida. Penggunaan pupuk kimia 
dianggap dapat memberikan nutrisi tambahan kepada tumbuhan sehingga cepat besar. Penggunaan pupuk kimia dan pestisida ini selain karena dikenalkan oleh pemerintah, juga karena ada warga Sipetung yang melihat petani di daerah lain menggunakan pupuk kimia dan pestisida.

Kebijakan pemerintah menyangkut pertanian masih terus berjalan sampai sekarang. Bantuan aneka bibit seperti bibit jagung hibrida, maupun benih padi unggul, bantuan tumbuhan-tumbuhan seperti pohon suren, mahoni dan alpokat, sering didapati masyarakat. Namun bantuan ini tidak diiringi dengan tata cara mengenai bagaimana pengelolaan tanaman tersebut. Penyuluh pertanian yang seharusnya mengemban tugas tersebut, tidak pernah datang untuk mencoba menjelaskannya kepada masya rakat. Untuk meningkatkan kesejahteraan masyarakat, pemerintah memberikan optima lisasi lahan kepada petani berupa hak guna penggunaan lahan hutan untuk tanaman pertanian. Hak guna ini disesuaikan dengan kerja sama antara pemerintah dengan masyarakat mengenai penyadapan getah pinus.

Selain faktor-faktor di atas, pengaruh yang lebih besar dalam perubahan adalah pembangunan daerah pegunungan. Hal ini termasuk pemba ngunan jalan, perbaikan sarana komunikasi dan transportasi, pertumbuhan penduduk, perubahan religi, dan yang sangat penting adalah penyesuaian secara terus menerus hubungan antara negara dan masyarakat. Salah satu bentuk pembangunan kawasan pedesaan yang dilakukan oleh pemerintah adalah perbaikan sarana transportasi. Pembangunan dan pelebaran jalan menuju Sipetung baru dimulai sekitar tahun 1987. Seiring dengan membaiknya perekonomian masyarakat dengan tanaman kopi, masyarakat sudah mulai mempunyai kenda raan bermotor. Berbagai kemudahan kredit motor ataupun ketersediaan kendaraan bekas, semakin memudahkan warga Sipetung untuk memilki motor. Perbaikan jalan dan masuknya angkutan umum memudahkan warga untuk pergi ke daerah lain dan juga mendistribusikan hasil pertanian ke pasar. Di sisi lain, hal ini juga menyebabkan cepatnya akses barang masuk ke Sipetung. Beberapa pedagang mulai masuk ke Sipetung untuk menjual aneka barang dagangan, baik berupa makanan, kebutuhan dapur sampai perabotan rumah tangga. Kemajuan transportasi ini telah mempengaruhi kegiatan pertanian, perdagangan dan melancarkan masyarakat untuk mengakses pekerjaan lain.

Perbaikan sarana telekomunikasi dan munculnya televisi juga memberikan dampak kepada masyarakat. Di setiap rumah yang saya kunjungi, selalu terlihat televisi. Televisi telah menjadi objek konsumsi bagi warga dan menjadi salah satu referensi bagi warga untuk berperilaku. Salah satu contohnya adalah bagaimana perubahan nama-nama anak di Sipetung. Kalau dulu, pemberian nama anak berkaitan dengan hari lahir berdasarkan kalender Jawa, sekarang mulai berubah, yaitu berdasarkan nama artis yang mereka tonton di televisi. Tidak aneh, kalau misalkan di Sipetung kita menjumpai nama anak seperti nama-nama pemain sinetron.

Beberapa warga Sipetung juga sudah mulai menggunakan handphone sebagai sarana telekomunikasi. Kepemilikan benda-benda jenis baru ini dilihat Hefner sebagai keinginan masyarakat supaya ingin dilihat sebagai anggota modern dari masyarakat nasional. Untuk mengesankan gaya dan bersaing dalam pasar, mereka mesti menarik diri semua ikatan masa lalu dan menginvestasikan kekayaan pada barang-barang modal yang tujuannya lebih produktif. Istilah praktisnya, investasi seperti tukar-menukar sumbangan akan terus menurun, sementara pemilikan bendabenda konsumsi jenis baru akan meningkat (Hefner, 1999: 315). Perluasan transportasi dan komunikasi di pedesaan dengan demikian telah memberikan dampak besar dalam membawa perubahan kehidupan di pedesaan dalam segi lain-lainnya. Selain memberikan kelancaran migrasi penduduk ke daerah lain, juga mempengaruhi perubahan-perubahan orientasi pandangan hidup, sikap dan perilaku pada masyarakat (Surjo, 1985: 36).

\section{E. Rasionalitas Petani dalam Menghadapi Transformasi}

$\mathrm{P}$ opkin (1979) mempunyai pemikiran bahwa ketika petani sudah melibatkan diri dalam ekonomi pasar, menanam komoditi, atau menjual tenaga kerja ke 
pasar, hal ini disebabkan bukan karena mereka merasa etika subsistensi mereka terancam, melainkan karena mereka melihat bahwa pasar menawarkan peluang kehidupan yang lebih baik daripada yang ada di desa. Dalam kondisi sosial ekonomi di dalam desa yang sedemikian payah, maka tanpa disuruhpun ketika ekonomi pasar merembes ke pedesaan kaum peasant akan berbondong-bondong me ngalir ke sana. Pemikiran Popkin ini seperti menggambarkan bagaimana kondisi petani di Sipetung.

Transformasi yang terjadi di interpretasi dan kemudian di respon oleh masyarakat. Bentuk respons ini adalah sebagai bentuk pemanfaatan peluang untuk kehidupan yang lebih baik. Pemilihan tanaman yang dianggap menguntungkan, intensifikasi lahan pertanian, pemanfaatan kawasan hutan dan mempertahan tanaman padi adalah contoh respons dari masyarakat agar bisa memajukan ekonomi mereka. Merujuk kepada pemikiran Hefner, Bourdieu, dan Mc Pherson, konsep "selera" atau "pilihan" (Hefner, 1999: 390), menjadi faktor yang melatarbelakangi respons masyarakat tersebut.

Dari contoh yang dijelaskan oleh Hefner di bukunya, pilihan individu tidak dapat dipahami lepas dari masyarakat dan budaya. Mereka membangun semacam "referensi sosial" atau mengangkat perasaan diri seseorang melalui identifikasi dan perbandingan dengan kelompok dan idealideal. Referensi sosial ini sering kali menggunakan "kelompok luar" sebagai model bagi aspirasi mereka. Perma salahannya di sini menurut Hefner adalah pada masalah pembangunan. Dalam konteks masyarakat yang sedang mem bangun, aspirasi sosial sangat mudah berubah karena mereka dapat dirangsang dalam berbagai bentuk produksi baru yang maju. Melalui tekanan yang lebih dalam kepada masyarakat, negara dan komunikasi mencangkokkan nilai elite dan kota ke kebanyakan desa-desa pinggiran. Keinginan umum akhirnya melampaui kemampuan masyarakat untuk menanggapi kebutuhan nya (Hefner, 1999: 395-403).

Proses pembangunan yang terjadi di Sipetung secara sadar telah ikut membuat proses modernisasi pada masyarakat. Perbaikan sarana transportasi, jalan, dan pembangunan sekolah, keberadaan televisi dan hanphone telah menyebabkan terjadinya re-orientasi budaya seperti yang dijelaskan oleh Hefner di atas. Informasiinformasi yang datang dari luar dengan cepat masuk kepada masyarakat. Informasiinformasi ini kemudian dipilah untuk menjadi "referensi sosial" berdasarkan "selera" masyarakat. Cerita mengenai keberhasilan petani di daerah bawah yang bisa naik haji gara-gara menanam sengon, menyebabkan timbulnya keinginan petani Sipetung untuk ikut menanam sengon. Model-model baru yang dibawa oleh orang luar, menimbulkan keinginan bagi masyarakat untuk melakukan hal yang sama. Warga berkeinginan untuk mempunyai motor baru, hanphone model baru, baju baru. Masyarakat ditarik dalam kebudayaan yang berada di luar komunitasnya. Pada akhirnya tingkat kebutuhan masyarakat menjadi menaik. Masyarakat harus memikirkan bagaimana upaya untuk bisa memenuhi kebutuhan tersebut. Menanam tanaman yang dianggap mempunyai nilai jual yang lebih tinggi dapat dijadikan sebagai salah satu alasan bagi warga untuk bisa memenuhi kebutuhannya tersebut.

\section{F. Kesimpulan}

$\mathrm{K}$ emampuan masyarakat Sipetung untuk bisa meningkatkan kesejah teraannya sangat tergantung pada bentuk respons mereka terhadap perubahan yang terjadi dan juga respons terhadap rekayasa pasar ataupun pemerintah. Berbagai bentuk respons masyarakat tersebut, kadang kala kandas karena adanya "rekayasa" yang dilakukan oleh pasar maupun pemerintah. Beberapa hasil pemilihan tanaman yang dilakukan oleh masyarakat bisa dilihat sebagai contohnya. Kasus jahe, cengkeh, Laos, dan sengon, pada saat penanaman, harga jual tanaman ini cukup tinggi, namun kemudian harga justru jatuh pada saat masyarakat mulai menanam. Peristiwa ini sering kali membuat rugi petani di Sipetung. Andai kata pola ini diterapkan kepada semua lahan yang ada, tentu petani di Sipetung akan masuk ke dalam kemiskinan. Berangkat dari pengalaman tersebut, masyarakat Sipetung mempertahan areal persawahan. Sawah dianggap sebagai jaminan hidup mereka. Praktek "coba-coba" hanya mereka terapkan di lahan perkebunan. 


\section{Daftar Pustaka}

Abdullah, Irwan. 2002. Tantangan Pembangunan Ekonomi dan Transformasi Sosial : Suatu Pendekatan Budaya. Jurnal Humaniora, Volume XIV, No. 3/2002. Universitas Gadjah Mada: Jogjakarta

Ahimsa, Heddy S. 2007. Paradigma, Epistemologi dan Metode IImu Sosial Budaya: Sebuah Pemetaan. Makalah dalam pelatihan "Metodologi Penelitian". 12 Februari-19 Maret 2007 Oleh CRCS - Universitas Gadjah Mada.

Arifin, Haswinar. 2008. Pendudukan Tanah, Diferensiasi Agraria, dan Perjuangan Petani Memperbaharui Akses atas Sumberdaya Agraria di Pedesaan. Makalah dalam Workshop on Agrarian and Rural Societies Transformation in Indonesia. 17-18 Juni 2008. Fakultas IImu Budaya, Universitas Gadjah Mada: Jogjakarta

Boomgaard, Peter. 2002. Jagung dan Tembakau di Dataran Tinggi Indonesia, 1600-1940 dalam Proses Transformasi Daerah Pedalaman di Indonesia, Disunting oleh Tania Murray Li. Yayasan Obor: Jakarta

Breeman, Jan dan Gunawan Wiradi. 2004. Masa Cerah dan Masa Suram di Pedesaan Jawa, Studi Kasus Dinamika Sosio-Ekonomi di Dua Desa Menjelang Akhir Abad ke20. LP3ES dan KITLV: Jakarta

Cahyono, Edi. 2005. Pekalongan 1830-1870: Transformasi Petani Menjadi Buruh Industri Perkebunan. Edi Cahyono's experiencE

Dobbin, Christine. 2008. Gejolak Ekonomi, Kebangkitan Islam, dan Gerakan Padri, Minangkabau 1784-1847. Diterjemahkan oleh Lilian D. Tedjasudhana. Komunitas Bambu: Jakarta

Geertz, Clifford. 1983. Involusi Pertanian, Proses Perubahan Ekologi di Indonesia. Bhratara Karya Aksara: Jakarta

Hart, G. A Turton, and Benyamin White, eds. 1989. Agrarian Transformation: Local Processes and the State in Southeast Asia. University of California Press: Barkeley and Los Angeles.

Hayami, Yujiro dan Masao Kikuchi. 1987. Dilema Ekonomi Desa, Suatu Pendekatan Ekonomi terhadap Perubahan Kelembagaan di Asia. Diterjemahkan oleh: Zahara D. Noer. Yayasan Obor: Jakarta

Hefner, Robert. W. 1999. Geger Tengger, Perubahan Sosial dan Perkelahian Politik. Dialihbahasakan oleh: A Wisnuhardana dan Imam Ahmad. LKIS: Yogyakarta

Huskens, Frans. 1998. Masyarakat Desa dalam Perubahan Zaman: Sejarah Diferensiasi Sosial di Jawa 1830 - 1980. PT Gramedia: Jakarta.

Jacobson, David. 1991. Reading Ethnography. State University of New York Press: New York.

Li, Tania M (Ed). 2002. Proses Transformasi Daerah Pedalaman di Indonesia. Yayasan Obor: Jakarta

2002. Keterpinggiran, Kekuasaan dan Produksi: Analisis terhadap Transformasi Daerah Pedalaman dalam Proses Transformasi Daerah Pedalaman di Indonesia, Disunting oleh Tania Murray Li. Yayasan Obor: Jakarta

Marzali, Amri. 2003. Strategi Peisan Cikalong dalam Menghadapi Kemiskinan. Yayasan Obor: Jakarta

Popkin, Samuel. L. 1986. Petani Rasional. Terjemahan oleh Sjahrir Mawi. Lembaga Penerbit Yayasan Padamu Negeri: Jakarta

Roseberry, William. 1994. Anthropologies and Histories, Essays in Culture, History, and Political Economy. Rutgers University Press: London

Saifuddin, Ahmad Fedyani. 2005. Antropologi Kontemporer, Suatu Pengantar Kritis Mengenai Paradigma. Kencana: Jakarta

Sairin, sjafri, Pujo Semedi dan Bambang Hudayana. 2002. Pengantar Antropologi Ekonomi. Pustaka Pelajar: Jogjakarta

Santoso, Harry. 2006. Renegoisasi Citra Lokal: Potret Transformasi Masyarakat Desa Hutan dalam Jurnal Analisis Sosial, Vol.11. No. 1 April 2006. Yayasan Akatiga: Bandung 
2011. Kontes Kekuatan di Dataran Tinggi dalam Jurnal Wacana, Edisi 25 Tahun XIII 2011. Insist: Jogjakarta

Schrauwers, Albert. "Itu Tidak Ekonomis" Sifat Ekonomi Moral yang Berakar Pada Ekonomi Pasar di Dataran Tinggi Sulawesi, Indonesia, dalam Proses Transformasi Daerah Pedalaman di Indonesia, Disunting oleh Tania Murray Li. Yayasan Obor: Jakarta

Scott, James. C. 1981. Moral Ekonomi Petani, Pergolakan dan Subsistensi di Asia Tenggara. LP3ES: Jakarta

Semedi, Pujo. 2006. Petungkriyono -Mitos Wilayah Terisolir- dalam Esei-esei Antropologi Teori, Metodologi \& Etnografi. Di Sunting oleh Heddy Shri Ahimsa Putra, HIm127143. Keppel Press: Jogjakarta

Singarimbun, Masri dan Dr. D.H Penny. 1984. Penduduk dan Kemiskinan, Kasus Sriharjo di Pedesaan Jawa. Diterjemahkan oleh Sulaiman Krisnandhi. Bhratara Karya Aksara: Jakarta

Spradley, James. P. 1997. Metode Etnografi. Diterjemahkan oleh Misbah Zulfra Elizabeth. Tiara Wacana: Jogjakarta

Suhartono. 1989. Apanage dan Bekel, Perubahan Sosial di Pedesaan Surakarta 1830 1920. Tiara Wacana: Jogjakarta

TPL (Tim Penelitian Lapangan). 1986. Masyarakat Petani Desa Yosorejo. Jurusan Antropologi: Jogjakarta

Tsing, Anna. L. 1998. Di Bawah Bayang-bayang Ratu Intan, Proses Marjinalisasi Pada Masyarakat Terasing. Diterjemahkan oleh A.F. Saifuddin. Yayasan Obor: Jakarta

Wertheim, W. F. 1999. Masyarakat Indonesia Dalam Perubahan, Studi Perubahan Sosial. Tiara Wacana: Jogjakarta

White, Benjamin. dan Gunawan Wirahadi. 1989. Agrarian and Nonagrarian Bases of Inequality in Nine Javanese Village. In Hart et al. 1989, 266-302 